\title{
ERDŐTÜZEK DINAMIKÁJÁNAK VIZSGÁLATA \\ A MEDGYESSY FERENC GIMNÁZIUMBAN
}

\section{Szerzők:}

Borbélyné Bacsó Viktória (PhD)

Medgyessy Ferenc Gimnázium, Múvészeti Szakgimnázium és Technikum

Szabó Dániel Dénes

Medgyessy Ferenc Gimnázium, Múvészeti Szakgimnázium és Technikum

Farkas Máté János

Medgyessy Ferenc Gimnázium, Múvészeti Szakgimnázium és Technikum

Ujvári Balázs (PhD)

Debreceni Egyetem

Első szerző e-mail címe: bacsoviktoria@gmail.com

\section{Lektorok:}

Kelemen Lajos (PhD)

Okoskocka Kft.

Szabóné Dr. Balogh Ágota (PhD)

Gál Ferenc Egyetem

...és további két anonim lektor

\section{Absztrakt}

Ez az összefoglaló egy olyan projektet mutat be, amelyben középiskolás diákok teszteltek szenzorokat egy erdőtüzek esetén adatgyújtésre képes mérōállomás prototípusához. E méróállomás autonóm kommunikációra képes és szükség esetén le lehet dobni egy helikopterról.

Kulcsszavak: erdőtúz, mérés, érzékelő

Diszciplinák: informatika, fizika, biológia

\section{Abstract \\ EXAMINING THE DYNAMICS OF FOREST FIRES \\ IN THE 'MEDGYESSY FERENC GIMNÁZIUM'}

This summary shows a project in which high school students tested sensors for a prototype of a measuring station that can collect data in forest fires. This measuring station can make autonomous communication, and that can be dropped from a helicopter if needed.

Keywords: forest fire, measurement, sensor

Disciplines: informatics, physics, biology 
Borbélyné Bacsó Viktória, Szabó Dániel Dénes, Farkas Máté János és Ujvári Balázs (2021): Erdőtüzek dinamikájának vizsgálata a Medgyessy Ferenc Gimnáziumban. Mesterséges intelligencia - interdiszciplináris folyóirat, III. évf. 2021/1. szám. 107-110. doi: 10.35406/MI.2021.1.107

Egyre nagyobb kárt okoznak az erdőtüzek. Éves szinten 3,4 millió négyzetkilométer zöld területet pusztítanak el (Bodnár, 2017, v.ö.: Spotts, 2011). A levegőbe kerülő szállópor az egészségügyi határérték fölötti mennyisége komoly tüneteket okozhat: károsíthatja a tüdőt, növelheti a szívroham és a stroke kockázatát. Sajnálatos módon jelenleg nem létezik az erdőtűz frontvonalának feltérképezésére szolgáló, terepi közvetlen mérést megvalósító eszköz, amelynek segítségével a lángok terjedését egyszerűbben lehetne feltartóztatni.

A Medgyessy Ferenc Gimnázium, Művészeti Szakgimnázium és Technikum diákjai az Emberi Erőforrások Minisztériuma által biztosított Útravaló/Út a tudományhoz (ÚT2020-0005) ösztöndíjprogramnak köszönhetően ösztöndíjasként foglalkozhattak e nem mindennapi problémával.
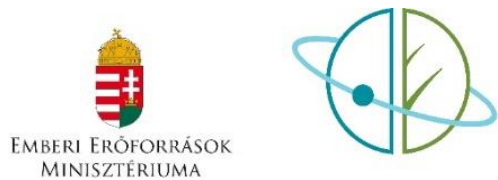

ÚT A TUDOMÁNYHOZ
Öt tanuló autonóm kommunikációra képes, helikopterről ledobható (v.ö.: Kós és Komjáthy, 2012) szenzoros mérőállomás prototípusának elkészítéséhez szükséges szenzorok tesztjét végezte el. A tervezett eszközön hőkamera, hőmérséklet, páratartalom, szállópor szenzorok (v.ö.: Szabó és Pirint, 2020) és mikrofon szolgál majd az azonnali adatgyüjtésre. A tervek szerint a prototípus egészen a megsemmisülés pillanatáig képes lesz kommunikációra és a tűzrôl begyưjtött információk továbbítására. Hogy a kommunikációra a mobil internet, netán az okos mérésre adekvátabb lehetőséget adó alacsony energiaigényű, nagy hatótávolságú, vezeték nélküli LoRa-rendszer biztosít majd lehetőséget, az a következő tanévre is átnyúló újabb vizsgálatoktól függ.

A mérésre a diákok a Medgyessy Ferenc Gimnáziumban és a Debreceni Egyetem Fizikai Innovációs Kutatóműhelyében készültek fel (Borbélyné, 2020), miközben szenzorokkal ismerkedtek, forrasztottak, programoztak, mérnöki munkát végeztek (1. ábra).

A kutatás dr. Ujvári Balázs egyetemi adjunktus és Borbélyné dr. Bacsó Viktória középiskolai fizikatanár irányításával folyt. A projekt megoldása során a mentorok egy olyan problémára, illetve annak elvi megoldására próbálták felhívni a tanulók figyelmét, amely az éghajlat változásával közvetlenül vagy közvetett módon emberek egyre nagyobb tömegének egészségét veszélyeztetheti. 
1. ábra: Munka köz̧ben. Forrás: a Szerzőke

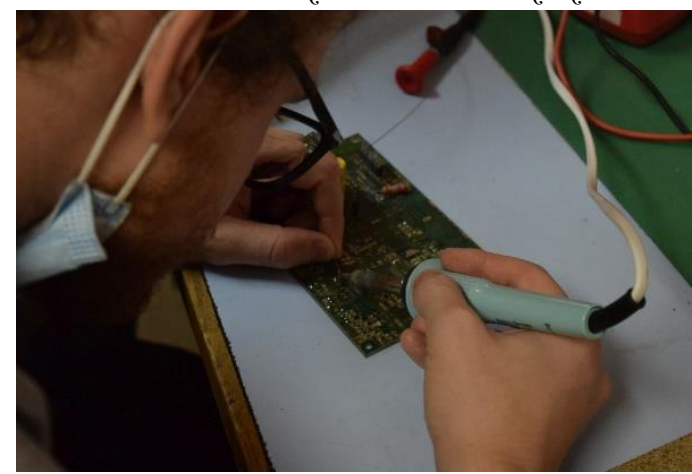

Eközben a diákok természet-tudományos, mérnöki és informatikai kom-petenciáik is jelentős mértékben fejlődtek.

A munka izgalmasabb szakaszában a tanulók az iskola udvarán a szabályokat betartva, a hatóságoktól a megfelelő tűzgyújtási engedélyt minden alkalommal kikérve gyújtottak „erdőtüzet” (2. ábra).

Különféle fafajták ágait elégetve hőkamerával figyelték a tűz hőmérsékletét. Megvizsgálták, hogy milyen összefüggés van az égő fa fajtája, a tűz hőmérséklete és a tűz hangja közt.

Miközben felvették a tűz hangját, meghatározták a frekvencia spektrumát, illetve azonosították a jellemző hangokat, amelynek kalibrációjához egy furulya hangjait használták, mint ismert frekvenciájú hangforrást (3. ábra)

Megfigyelték, hogy a tűz hőmérséklete, amit csak szűk határok közt tudtunk változtatni, nem befolyásolta a jellemző frekvenciákat, csak a hangok amplitúdóját, azaz egy fajta ág
2. ábra: A vizsgálatokhoz. szüleséges „erdôtür, szimuláciō" és méröeszközök (forrás: a Szerzőo)
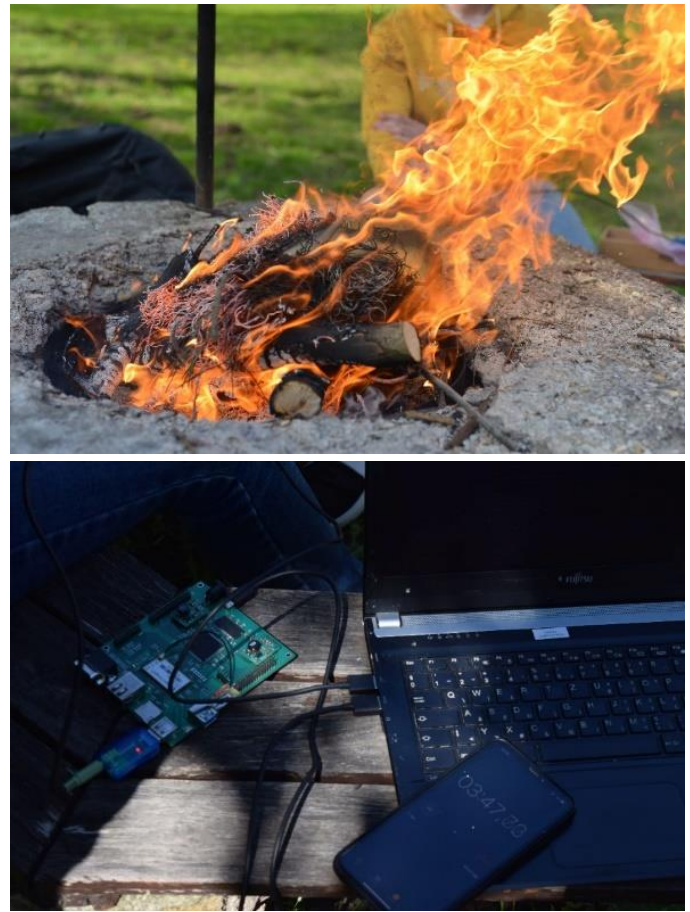

3. ábra: Kalibráció furulyával. Forrás: a Szerzọo

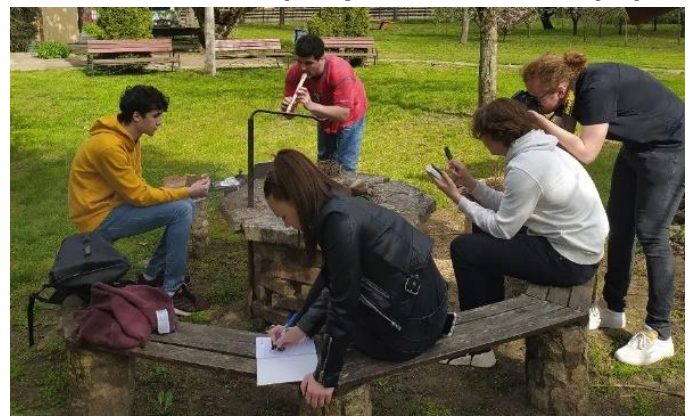


ugyanúgy ropogott a tüzben, csak magasabb hőmérsékleten hangosabban, aktívabban jelent meg az adott hang.

A diákok a mérések során azt is megfigyelték, hogy legtöbb esetben egyenesen arányosan növekszik a szállópor és a hőmérséklet értéke, azonban néhol ez mutat eltéréseket. Az adatokat a tanulók jelenleg is értékelik. A szállópor mérése azért is volt különösen fontos számukra, mert egy tűzoltás szempontjából releváns adatokat szolgáló rendszert szeretnének elkészíteni. A kapott értékekkel könnyen meghatározható egy füstszűrő élettartama az adott tűzben, így ennek túltelítődése nem válik veszélyessé.

A tanulók feltételezése szerint műszerüket az erdőtűz frontvonala elé helyezve, az összegyújtött adatokból következtetni lehet a tûz tulajdonságaira, megállapítható, hogy milyen gyorsan mozog a tüz és épp milyen fafajták égnek benne. Feltehetően ezzel előre lehetne jelezni, hogy milyen ütemben fognak a lángok a következő percekben haladni

A probléma fontosságára a tanulók a Debreceni Egyetem Fizikai Innovációs Kutatómúhelyének év végi konferenciajján szélesebb hallgatói és oktatói tömegek előtt is felhívták a figyelmet. S hogy nem csak a diákok viselik szívükön a témát, azt az is mutatja, hogy az Útravaló program anyagi támogatás nyújtott a kivitelezéshez, a
Sensirion cég pedig szenzorokkal segítette a munkát.

\section{Irodalom}

Bodnár L. (2017): Erdőtűz megelőzés korszerű módszer segítségével. Hadmérnök, XII. évf., 1. különszám (2017. július). 5969.

Borbélyné Bacsó Viktória (2020): Fizikai Innovációs Kutatóműhely - Középiskolás diákok kutatómunkája Debrecenben. OxIPO - interdiszciplináris tudományos folyóirat, 2020/1, 85-87. doi: 10.35405/OXIPO.2020.1.85

Kós GY. és Komjáthy L. (2012): Erdőtüzek helikopteres oltása. Repüléstudományi közlemények, 242 (2012) p. 471- 482.

Spotts, P. (2011): Raging wildfires: Climate changes to blame for record season?. Letöltés: 2021.06.20. Web: https://www.csmonitor.com/Environme nt/2011/0711/Raging-wildfires-Climatechanges-to-blame-for-record-season

Szabó Dániel Dénes és Pirint Róbert Olivér (2020): Felhőben az egészségünk. Mesterséges intelligencia - interdiszcip-lináris folyóirat, II. évf. 2020/2. szám. 73-86. doi: 10.35406/MI.2020.2.73 